\title{
The use of digital photos to assess visual cover for wildlife in rangelands
}

\author{
Cameron N. Carlyle ${ }^{a}$, Lauchlan H. Fraser ${ }^{b, *}$, Cindy M. Haddow ${ }^{c}$, Becky A. Bings ${ }^{d}$, William Harrower ${ }^{a}$ \\ ${ }^{a}$ Dept. of Botany, University of British Columbia, Vancouver, BC V6T 1X1, Canada \\ ${ }^{\mathrm{b}}$ Dept. of Natural Resource Sciences, Thompson Rivers University, 900 McGill Road, PO Box 3010, Kamloops, BC V2C 5N3, Canada \\ ${ }^{\mathrm{c}}$ Range Specialist, Ecosystems Branch, Environmental Stewardship Division, Ministry of Environment PO Box 9338, Stn, Prov Govt, Victoria, BC V8W 9M1, Canada \\ ${ }^{\mathrm{d}}$ Ecosystem Biologist, Cariboo Region, Ministry of Environment, 400-640 Borland St., Williams Lake, BC V2G 4T1, Canada
}

\section{A R T I C L E I N F O}

\section{Article history:}

Received 26 August 2009

Received in revised form

3 February 2010

Accepted 10 February 2010

\section{Keywords:}

Bunchgrass

Digital image analysis

Grazing

Litter

Range management

Robel pole

Wildlife management

\begin{abstract}
A B S T R A C T
Grassland vegetation can provide visual cover for terrestrial vertebrates. The most commonly used method to assess visual cover is the Robel pole. We test the use of digital photography as a more accurate and repeatable method. We assessed the digital photography method on four forage grassland species (Pseudoroegneria spicata, Festuca campestris, Poa pratensis, Achnatherum richardsonii). Digital photos of 2-dimensional cutout silhouettes of three bird species sharp-tailed grouse, western meadowlark and savannah sparrow were used to model the impact of clipping (i.e., grazing) on visual cover. In addition, photos of artificial voles were used to model litter on cover available to small mammals. Nine sites were sampled and data were analyzed by the dominant grass species in each study plot. Regression analysis showed that digital photos $\left(r^{2}=0.62\right)$ were a better predictor than the Robel pole $\left(r^{2}=0.26\right)$ for assessment of cover. Clipping heights showed that clipping at less than $15 \mathrm{~cm}$ left the silhouettes $50 \%$ exposed. Digital photo analysis revealed that visual cover was affected by the type of grass species, with F. campestris $>$ P. pratensis $>A$. richardsonii $>$ P. spicata. Biomass and litter were both positively related to cover for small mammals.
\end{abstract}

(C) 2010 Elsevier Ltd. All rights reserved.

\section{Introduction}

Amount and type of vegetative cover can affect ground-nesting bird success (Kirsch, 1974; Duebbert and Lokemoen, 1976; Martin and Roper, 1988; Hernández et al., 2003). Grazing alters the structure of grasslands through the removal of plant biomass, thus potentially increasing the susceptibility of ground-nesting birds, as well as small grassland mammals, to predation. The resulting loss of suitable habitat and increased predation risk due to grazing may be a contributing factor to the decline in grassland bird populations in western rangelands (Ammon and Stacey, 1997; Brennan and Kuvlesky, 2005).

To manage sustainable range use for cattle and wildlife it is necessary to understand the effects of grazing on parameters of wildlife habitat, such as vegetative cover. The Robel pole was devised as a method to non-destructively estimate grassland productivity; it has since been adapted for measurement of habitat characteristics in relation to concealment in ground cover for small mammals and particularly birds (Robel et al., 1970). Increased grazing pressure reduces the visual cover reading obtained by the Robel pole (Reese et al., 2001; West and Messmer, 2006). There is

\footnotetext{
* Corresponding author. Tel.: +1 250377 6135; fax: +1 2508285450 .

E-mail address: Ifraser@tru.ca (L.H. Fraser).
}

evidence that greater visual cover readings are found at bird nesting sites compared to non-nesting sites (e.g., Fondell and Ball, 2004; Pitman et al., 2005; West and Messmer, 2006). However, other studies which modeled habitat characteristics and included Robel pole readings in their initial site characterization found that the pole readings had little explanatory power (e.g Moynahan et al., 2006; Renfrew et al., 2005; Warren and Anderson, 2005; Winter et al., 2005). A problem is that the Robel pole is limited by a potential observer bias and possible subjectivity in measurement (Gotfryd and Hansell, 1985; Block et al., 1987; Ganguli et al., 2000; Collins and Becker, 2001; Limb et al., 2007). If the Robel pole method contains excessive measurement error, it is difficult to make sound conclusions on the assessment of wildlife habitat. This observation led us to the consideration of digital photography as a potentially more representative means of assessing the vegetative cover provided by standing vegetation.

If photo imaging is a more accurate tool than the Robel pole to assess vegetative cover, photo imaging can be used to perform better tests of the effects of grazing and vegetation composition on wildlife habitat parameters. Structural heterogeneity found in grasslands supports diverse and stable wildlife populations (McGarigal and McComb, 1995). Rapid and accurate quantification of vegetation structure is essential to assessing wildlife habitat, especially avian habitat (McGarigal and McComb, 1995; Sutter and 
Brigham, 1998). Photo techniques have been used for other applications such as canopy gap analysis, biomass estimation and for novel applications such as non-destructive biomass sampling of shrubs (Boyd and Svejcar, 2005; Limb et al., 2007). Here, we expand the photo analysis tool to apply to vegetative cover for birds and small mammals in rangelands.

We tested for differences in vegetative cover provided by four dominant grass species in the grasslands of the southern interior of British Columbia, Canada, and that represent an important forage for cattle: bluebunch wheatgrass (Pseudoroegneria spicata [Pursh] A. Löve), rough fescue(Festuca campestris Rybd.), Kentucky bluegrass (Poa pratensis L.), spreading needlegrass (Achnatherum richardsonii [Link] Barkworth) (Tisdale, 1947). We tested vegetative cover for three ground-nesting birds found in the southern interior grasslands of British Columbia, Canada: sharp-tailed grouse (Tympanuchus phasianellus), western meadowlark (Sturnella neglecta) and savannah sparrow (Passerculus sandwhichensis) (Fraser et al., 1999). These birds represent a range in size scale from the relatively small sparrow, to medium meadowlark, to large grouse. We also tested vegetative cover for voles. Voles, particularly the montane vole (Microtus montanus), construct runs and nests in the litter layer of grasslands and are important prey for endangered burrowing owls and badgers (Todd et al., 2003).

The objectives of this study were to: 1) Examine the accuracy of digital photography compared to the Robel pole in assessing vegetative cover; 2) Model the effect of controlled clipping of grassland vegetation on cover provided to three ground-nesting birds; 3 ) Examine the variation in cover across four important forage grass species; and, 4) Measure the effect of litter removal on the cover provided to small mammals.

\section{Methods}

\subsection{Study sites}

The study area was located in the southern interior grasslands of British Columbia, Canada. The soils in the study area are Orthic Dark Brown Chernozems, mean annual temperature is $4{ }^{\circ} \mathrm{C}$, and mean annual precipitation is $250-450 \mathrm{~mm}$, depending on location. Nine sites were selected, six in Lac du Bois Provincial Park, British Columbia (UTM10 E0680738 N5626223) and three near Williams Lake, British Columbia (UTM10 E0541492 N5759574) during the summer of 2005. Sites were located in grazed and ungrazed pastures and were chosen to represent a range of native grassland types. Locations ranged from 712 to $1000 \mathrm{~m}$ a.s.l., biomass at the sites ranged from $109 \mathrm{~g} / \mathrm{m}^{2}$ to $204 \mathrm{~g} / \mathrm{m}^{2}$, and litter amounts ranged from $41.7 \mathrm{~g} / \mathrm{m}^{2}$ to $269.9 \mathrm{~g} / \mathrm{m}^{2}$ (Carlyle, unpublished data)

\subsection{Stem height, Robel pole and digital photos of bird species silhouettes}

At each of the nine sites, a $50 \mathrm{~m}$ transect was established, and twenty-five $0.5 \times 0.5 \mathrm{~m}$ plots were examined every $2 \mathrm{~m}$ along the transect. Stem height, excluding inflorescences, of the dominant grass species at each plot was measured before clipping. Visual obscurity was measured with a Robel pole (Robel et al., 1970) and with a digital photo (see Limb et al., 2007), both taken from $4 \mathrm{~m}$ away and $1 \mathrm{~m}$ above ground level. Photos were taken with a Konica Minolta Dimage Z2 (4 mega pixels and a resolution of $2272 \times 1704$ pixels) within a 3 -h period during mid-day11:00-14:00 in July. Vegetation was successively clipped to 25,20 , 15,10 , and $5 \mathrm{~cm}$ from ground level. At each clipping level visibility measurements were done with a Robel pole and digital photos.

The Robel pole is a $2.5 \mathrm{~cm}$ diameter pole divided into $2.5 \mathrm{~cm}$ alternating black and white bands, the lowest visible band is recorded. Digital photos were taken of life size cutouts of three grassland birds: savannah sparrow, western meadowlark and sharp-tailed grouse. We selected these three birds because they are dependent on grasslands that provide vegetative cover and litter (Fraser et al., 1999). The cutouts were painted a fluorescent orange (see Photo Analysis below for explanation) and placed standing vertically in the grassland.

\subsection{Digital photos of artificial small mammals}

Fluorescent orange dowels (cylindrical pieces of wood $10 \mathrm{~cm}$ long $\times 2.5 \mathrm{~cm}$ diameter) were used as artificial voles to measure the cover provided by litter. Four dowels were placed within each corner of a $0.5 \times 0.5 \mathrm{~m}$ quadrat. If litter was present, we assumed that the voles could likely use the litter as cover; therefore, the dowel was positioned under the litter. A digital photo, with a nadir view, was taken from $1 \mathrm{~m}$ above the ground with the dowels placed first beneath any litter that may have been present, and then with the litter removed. Evidence of small mammal activity (tunnels, feces, and nests) in the plot was recorded (either present or absent). The litter and the above ground live plant biomass were collected, dried for $48 \mathrm{~h}$ at $65{ }^{\circ} \mathrm{C}$ in a forced-air drying oven and weighed.

\subsection{Photo analysis}

Each digital photo was analyzed using GIMP's colour select tools which counts the number of pixels of a specified colour in a photo (Kimball and Mattis, 2006, an open-source software package). The cutouts and dowels were painted fluorescent orange so that they contrasted with the surrounding vegetation. For each photo, we used the colour select tool and identified the fluorescent orange on the cutouts or dowels. Different lighting and shading within a single photo, and between photos, created a range of hues of the fluorescent orange. The threshold setting for the colour select tool determined the range of hues associated with the fluorescent orange. We determined that a setting of 40 selected most of the visible parts of the cutouts while minimizing the amount of unintentional selection. When sections of the photo other than the cutouts or dowels were unintentionally selected, due to the similarity of hues (e.g., orange-brown grasses in senescence), these sections of the photo were coloured white to remove them from the count. The cutouts and dowels were all photographed in their entirety (i.e., no vegetation) for the maximum number of pixels, which served as the reference photo. The number of pixels in field photos was then divided by the reference photo to obtain a percentage of pixels visible in each photo.

\subsection{Data analysis}

Linear regression was used to model the relationships amongst the digital photos, Robel pole, cutting levels $(25,20,15,10$, and $5 \mathrm{~cm}$

\section{Table 1}

Mean values of biomass $(\mathrm{g})$, litter $(\mathrm{g})$, stem height $(\mathrm{cm})$, and Robel pole readings $(\mathrm{cm})$ in $0.25 \mathrm{~m}^{2}$ plots dominated by one of four species: bluebunch wheatgrass, rough fescue, Kentucky bluegrass, and spreading needlegrass. Numbers in parentheses are \pm standard error

\begin{tabular}{llllr}
\hline $\begin{array}{l}\text { Dominant } \\
\text { grass species }\end{array}$ & $\begin{array}{l}\text { Mean plot } \\
\text { biomass }(\mathrm{g})\end{array}$ & $\begin{array}{l}\text { Mean plot } \\
\text { litter }(\mathrm{g})\end{array}$ & $\begin{array}{l}\text { Mean stem } \\
\text { height }(\mathrm{cm})\end{array}$ & $\begin{array}{l}\text { Mean Robel } \\
\text { pole }(\mathrm{cm})\end{array}$ \\
\hline $\begin{array}{c}\text { Bluebunch } \\
\text { wheatgrass }\end{array}$ & $41.32(3.3)$ & $15.30(2.3)$ & $36.35(1.1)$ & $7.46(1.0)$ \\
$\begin{array}{l}\text { Rough fescue } \\
\text { Kentucky } \\
\text { bluegrass }\end{array}$ & $50.58(3.1)$ & $48.65(5.6)$ & $42.10(1.2)$ & $10.36(0.8)$ \\
$\begin{array}{c}\text { Spreading } \\
\text { needlegrass }\end{array}$ & 48.96(3.4) & $29.41(5.4)$ & $20.00(0.7)$ & $5.52(0.5)$ \\
\hline
\end{tabular}


Table 2

Linear regression analyses for digital photo (percent of cutout visible), Robel pole, height of clipping $(25,20,15,10$, and $5 \mathrm{~cm}$ from ground level), and undisturbed stem height (measured in unclipped plots). All $P<0.001$.

\begin{tabular}{lcc}
\hline Regression model & $r^{2}$ & $\begin{array}{l}\text { Degrees of } \\
\text { freedom }\end{array}$ \\
\hline Digital photo vs. height of clipping & 0.62 & 3774 \\
Robel pole vs. height of clipping & 0.26 & 3774 \\
Digital photo vs. undisturbed stem height & 0.16 & 567 \\
Robel pole vs. undisturbed stem height & 0.00 & 567 \\
Digital photo vs. Robel pole & 0.14 & 3778 \\
\hline
\end{tabular}

from ground level), and undisturbed stem height. Linear regression was also used to model the relationship between cutting height and visibility in the photo for each species of cutout combined across dominant grass species and separately for each dominant grass species. Grass species with few occurrences, such as stiff needlegrass (Achnatherum occidentale Thurb.), were included in cross-species analysis but not analyzed individually. The coefficients from these regressions were then used to calculate the estimated clipping height required to produce a given percent visibility of the cutouts. A two-way analysis of variance (ANOVA) was completed to test for differences between the mean visibility of the cutouts for different dominant grass species.

The visibility of the dowels was regressed against both biomass and litter weight. All data was $\log _{10}(x+1)$ transformed to meet the assumptions of normally distributed data for the parametric tests. The coefficients were then used to model the amount of biomass and litter present to provide cover for the dowels (i.e., small mammals).

Only the Lac du Bois data were used to model and compare dominant grass species as visual cover. All analyses were done using the R statistical package (R Development Core Team, 2006).

\section{Results}

The mean biomass of the plots, when separated to dominant grass species, ranged from $38.96 \mathrm{~g} \pm 3.4 \mathrm{SE}$ to $50.58 \mathrm{~g} \pm 3.1 \mathrm{SE}$, litter from $15.3 \mathrm{~g} \pm 2.3 \mathrm{SE}$ to $53.31 \mathrm{~g} \pm 6.7 \mathrm{SE}$, stem height from $20.0 \mathrm{~cm} \pm 0.7 \mathrm{SE}$ to $42.10 \mathrm{~cm} \pm 1.2$ SE and Robel pole readings from $5.0 \pm 1.9 \mathrm{~cm}$ to $10.36 \mathrm{~cm} \pm 0.8 \mathrm{SE}$ (Table 1 ).

The highest correlation was between the digital photos and the height of clipping (Table 2). The Robel pole measurements and stem height of the dominant plant species before clipping have low correlation with each other, the height of clipping and the values obtained with the digital photos.
Table 3

Mean percent visibility of three bird cutouts (sharp-tailed grouse, western meadowlark, savannah sparrow) for each of the four dominant grass species using digital imagery software. Numbers in parentheses are \pm standard error.

\begin{tabular}{lrrr}
\hline \multirow{2}{*}{ Dominant grass } & \multicolumn{3}{l}{ Mean percent visibility } \\
\cline { 2 - 4 } & \multicolumn{1}{c}{ Grouse } & Meadowlark & \multicolumn{1}{c}{ Sparrow } \\
\hline Bluebunch wheatgrass & $25.4(2.9)$ & $27.3(2.8)$ & $22.5(2.6)$ \\
Rough fescue & $7.5(1.8)$ & $5.2(1.4)$ & $3.1(1.0)$ \\
Kentucky bluegrass & $13.1(1.8)$ & $12.8(1.9)$ & $6.4(1.1)$ \\
Spreading needlegrass & $13.5(2.5)$ & $10.3(1.9)$ & $4.46(0.8)$ \\
\hline
\end{tabular}

Linear regression models estimated that $50 \%$ visibility of the cutouts occurred at $14.3 \mathrm{~cm}, 13.6 \mathrm{~cm}$ and $9.8 \mathrm{~cm}$ for the grouse (intercept $=0.89$, slope $=-0.03$ ), meadowlark (intercept $=0.90$, slope $=-0.03$ ) and sparrow (intercept $=0.79$, slope $=-0.03$ ) respectively across all dominant grass species. Three two-factor ANOVAs testing the effects of clipping and dominant grass species on the visibility of each cutout type separately showed that clipping reduced the cover for the cutouts (grouse: $F=4.99 P<0.001$; meadowlark: $F=6.1, P<0.001$; sparrow: $F=6.60, P<0.001)$. The dominant grass species also altered the visibility of the cutouts (grouse: $F=1.12, P<0.001$; meadowlark: $F=1.31, P<0.001$; sparrow: $F=1.09, P<0.001)$. None of the interactions were significant.

Of the four grass species, bluebunch wheatgrass provided the least cover to the cutouts while rough fescue provided the greatest cover (Table 3). The clipping height at which cutouts were 50\% visible ranged from 10.9 to $19.9 \mathrm{~cm}$ for the grouse, $10.5-19.4 \mathrm{~cm}$ for the meadowlark and $6.8-14.1 \mathrm{~cm}$ for the sparrow (Table 4).

The visibility of the dowels was significantly influenced by the amount of live biomass and litter (Fig. 1). A linear model estimates that, with all sites pooled, $25 \mathrm{~g}$ per $0.25 \mathrm{~m}^{2}$ of standing biomass was needed to provide approximately $50 \%$ cover after litter was removed (intercept 0.37 , slope $=-0.14$ ). Similarly, $5.3 \mathrm{~g}$ of litter was required to obscure $50 \%$ of the dowels when vegetation was present (intercept $=0.30$, slope $=-0.15$ ).

\section{Discussion}

\subsection{Evaluation of digital photography to assess vegetative cover}

Our results show that the Robel pole, a common tool to assess visual cover for wildlife, was less reliable than digital photos for the measurement of visual cover (also see Limb et al., 2007). The accuracy of the Robel pole is limited by (1) the small diameter of the

Table 4

Linear regression models to predict the stubble height $(\mathrm{cm})$ required for visual cover of three bird species in four species of forage grasses.

\begin{tabular}{|c|c|c|c|c|c|c|c|c|c|c|c|c|}
\hline & \multirow[t]{2}{*}{ Grass species } & \multirow[t]{2}{*}{$\begin{array}{l}\text { Degrees of } \\
\text { freedom }\end{array}$} & \multirow[t]{2}{*}{$r^{2}$} & \multirow[t]{2}{*}{$f$-value } & \multirow[t]{2}{*}{ Intercept } & \multirow[t]{2}{*}{ Slope } & \multicolumn{6}{|c|}{$\begin{array}{l}\text { Stubble height }(\mathrm{cm}) \text { required for the visual } \\
\text { obstruction of birds at six different percent visibility } \\
\text { values. }\end{array}$} \\
\hline & & & & & & & $0 \%$ & $10 \%$ & $25 \%$ & $50 \%$ & $75 \%$ & $90 \%$ \\
\hline \multirow[t]{4}{*}{ Grouse } & Bluebunch wheatgrass & 156 & 0.42 & 111 & 0.942305 & -0.022188 & 42.5 & 38.0 & 31.2 & 19.9 & 8.7 & 1.9 \\
\hline & Rough fescue & 206 & 0.73 & 544 & 0.787143 & -0.026438 & 29.8 & 26.0 & 20.3 & 10.9 & 1.4 & -4.3 \\
\hline & Kentucky bluegrass & 213 & 0.6 & 320.3 & 0.788156 & -0.022702 & 34.7 & 30.3 & 23.7 & 12.7 & 1.7 & -4.9 \\
\hline & Spreading needlegrass & 83 & 0.69 & 181.8 & 0.786405 & -0.022164 & 35.5 & 31.0 & 24.2 & 12.9 & 1.6 & -5.1 \\
\hline \multirow[t]{4}{*}{ Meadowlark } & Bluebunch wheatgrass & 157 & 0.41 & 107.3 & 0.97143 & -0.02424 & 40.1 & 36.0 & 29.8 & 19.4 & 9.1 & 2.9 \\
\hline & Rough fescue & 204 & 0.71 & 487.6 & 0.800733 & -0.028759 & 27.8 & 24.4 & 19.1 & 10.5 & 1.8 & -3.5 \\
\hline & Kentucky bluegrass & 212 & 0.59 & 310.2 & 0.823635 & -0.025687 & 32.1 & 28.2 & 22.3 & 12.6 & 2.9 & -3.0 \\
\hline & Spreading needlegrass & 82 & 0.7 & 192.2 & 0.82166 & -0.02427 & 33.9 & 29.7 & 23.6 & 13.3 & 3.0 & -3.2 \\
\hline \multirow[t]{4}{*}{ Sparrow } & Bluebunch wheatgrass & 154 & 0.41 & 105.3 & 0.856815 & -0.025387 & 33.8 & 29.8 & 23.9 & 14.1 & 4.2 & -1.7 \\
\hline & Rough fescue & 191 & 0.61 & 302.7 & 0.693038 & -0.028384 & 24.4 & 20.9 & 15.6 & 6.8 & -2.0 & -7.3 \\
\hline & Kentucky bluegrass & 205 & 0.55 & 249 & 0.717835 & -0.026952 & 26.6 & 22.9 & 17.4 & 8.1 & -1.2 & -6.8 \\
\hline & Spreading needlegrass & 81 & 0.66 & 158.3 & 0.723923 & -0.026441 & 27.4 & 23.6 & 17.9 & 8.5 & -1.0 & -6.7 \\
\hline
\end{tabular}



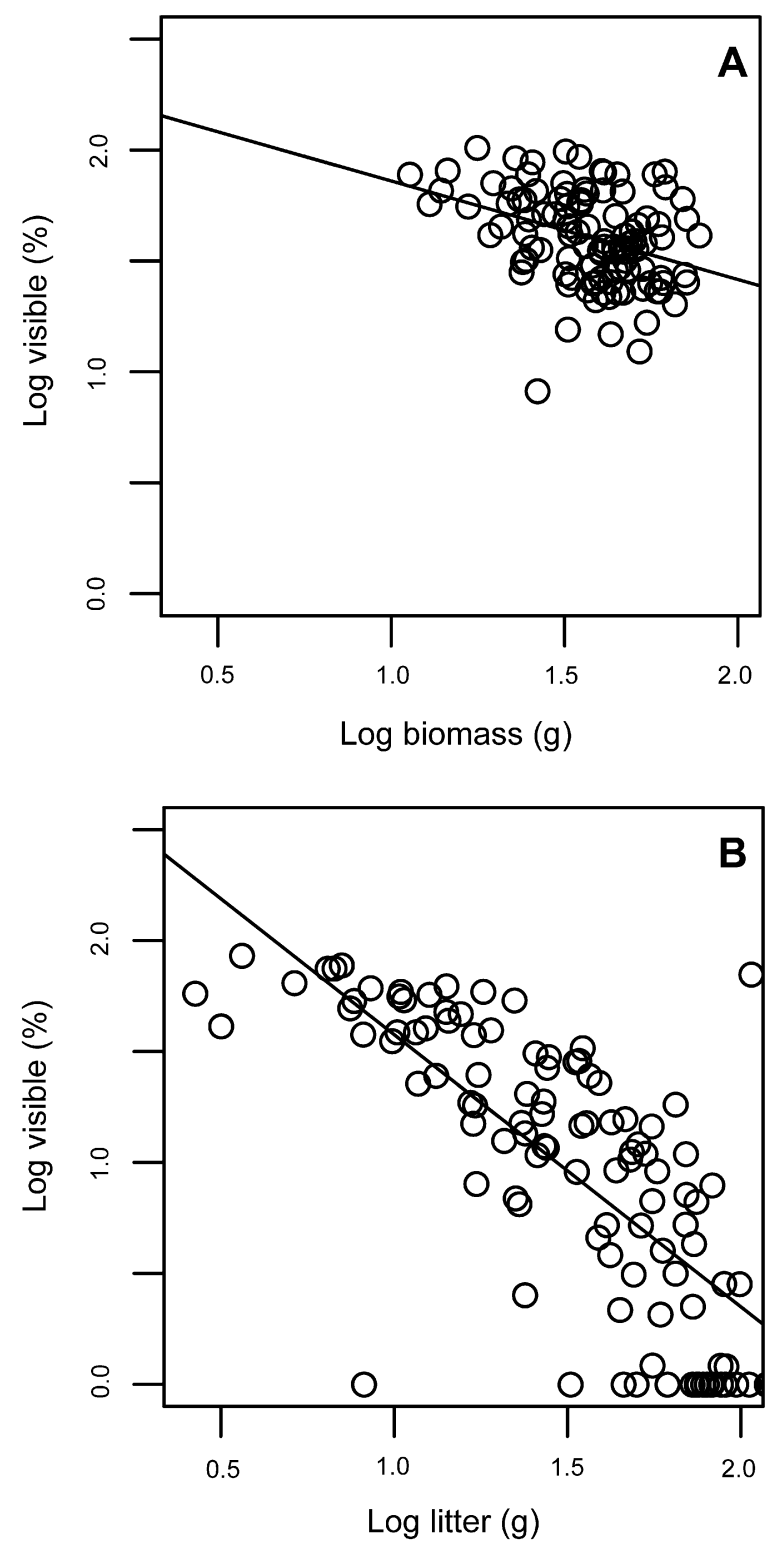

Fig. 1. Relationship of the visibility of the dowels (i.e., artificial voles) with vegetative biomass $(\mathrm{g})$ and litter $(\mathrm{g})$ from $0.25 \mathrm{~m}^{2}$ plots. All axes are log transformed, $\log _{10}(x+1)$. A, Litter was removed from the plot for the analysis of biomass $\left(r^{2}=0.15, P<0.001\right.$, $\mathrm{df}=107, F$-statistic $=19.38)$. B, Biomass and litter were present in the plot for the analysis of litter $\left(r^{2}=0.61, P<0.001, \mathrm{df}=107, F\right.$-statistic $\left.=166\right)$.

pole $(2.5 \mathrm{~cm})$; (2) the discreet $2.5 \mathrm{~cm}$ measurement units along the length of the pole; and, (3) the subjectivity of observer error. Digital photography is also discreet because it is limited to the number of pixels in the digital image, but the measurement is essentially continuous due to the large number of pixels in each photo. However, digital photography is often more labour intensive than the Robel pole; more field work is required plus photo processing on a computer. One way to reduce the labour is to limit the number of photos or the number of different cutouts. We used silhouettes of three different grassland birds but a single coloured board could be used instead.

\subsection{Effect of clipping on vegetative cover}

As expected, clipping reduced the amount of vegetative cover for all four of the forage grasses considered. However, the effect of clipping varied by grassland species, and the difference generally seemed to be a result of the form and structure of the grass species. For example, rough fescue provided the most cover, and it is a $40-90 \mathrm{~cm}$ tall bunchgrass, densely tufted, which can form large, $30-60 \mathrm{~cm}$ diameter tussocks in relatively productive sites (Hitchcock and Cronquist, 1973). Much of the cover provided by this species was probably due to these pronounced tussocks. Alternatively, bluebunch wheatgrass, which provided the least cover, is a relatively sparse bunchgrass with thin leaves and does not tend to form the large tussocks associated with rough fescue (Hitchcock and Cronquist, 1973). Spreading needlegrass supported moderate visible cover. Although tall, with culms up to $100 \mathrm{~cm}$, needlegrass produces relatively small tussocks (Hitchcock and Cronquist, 1973). Kentucky bluegrass, a sod forming grass, has been widely distributed due to its grazing-tolerant characteristics. Bluegrass' cover was comparable to needlegrass. Since rough fescue provides the greatest vegetative cover for grassland birds, it might be expected that a greater number of bird nests would be found in rough fescue patches. If so, range managers should consider grazing practices that support rough fescue, or similar tussock-forming grasses.

Complete visibility can only be achieved if the cutout was sitting above the ground. Furthermore, clipping did not go below $5 \mathrm{~cm}$ so $100 \%$ visibility was rarely possible unless the cutout was sitting on high ground. Generally, cutouts were sitting on lower ground because grass hummocks had a tendency to raise the ground between the cutout and camera. As a result, the regression indicates negative clipping values to produce high visibility. This may cause an underestimation of the clipping height necessary to provide a given amount of cover.

\subsection{Cover for small mammals}

The amount of litter and live vegetation directly affected the vegetative cover given to the artificial small mammals. Our results suggest that small mammals would have better visual cover based on litter availability. Since grazing reduces litter quantity, grazing likely reduces visual cover for small mammals. Small scale site selection based on vegetation characteristics has been observed in Microtus species (Bias and Morrison, 2006; Luque-laren and López, 2007). Therefore, even a patchy distribution of litter should provide adequate cover for small mammals. Small mammals are an essential part of the grassland food web, and range managers should consider grazing practices that provide litter. Live biomass also provided visual cover, but live biomass alone explained less of the variation in small mammal (dowel) visibility.

\subsection{Management implications}

Previous research supports the concept that dense, residual cover can increase the success of ground-nesting birds, often through reduced predator efficiency (Kirsch, 1974; Duebbert and Lokemoen, 1976; Martin and Roper, 1988; Hernández et al., 2003). Our data can provide guidelines for a minimum level of cover for grassland birds and small mammals based on stubble (clipping or grazing) height, biomass and litter. The results indicate that stubble heights of $15 \mathrm{~cm}$ or less would leave all three of the bird cutout species more than $50 \%$ exposed. How a visibility of $50 \%$ for a cutout translates to an actual animal is unknown. Obviously, other factors will affect cover including animal behaviour and camouflage, but considering the fact that cover in general is important for nest success (as evidenced by the studies cited above), being able to accurately quantify cover classes is very important.

Results from the litter study indicate that to manage rangelands to support small mammals, litter levels and standing biomass must be high. Rough fescue provided the most cover, and estimates 
showed that its ability to provide cover was the most resistant to clipping. However, this does not imply that grazing resulting in a lower stubble height in rough fescue is less detrimental because it does not take into account other benefits provided by the grass or incorporate the long-term effects of disturbance. The tradeoffs between wildlife and range requirements need to be considered.

\section{Conclusions}

Vegetation in grassland ecosystems provides visual cover for birds and small mammals. Our comparative test of the Robel pole and digital photography methods to assess visual cover demonstrated that the use of digital photography was a more accurate and repeatable method on the four forage grassland species ( $P$. spicata, F. campestris, $P$. pratensis, $A$. richardsonii). Clipping heights showed that clipping at less than $15 \mathrm{~cm}$ left the silhouettes 50\% exposed. Biomass and litter were both positively related to cover for small mammals.

Future work is needed to manipulate the amount of vegetation, litter, and cover in a manner consistent with rangeland use, and to monitor the population dynamics and behavioural response of wildlife. The requirements are likely to vary depending on, for example, the species being considered, grassland type, pasture size, predation risk, the type of predator and nest site availability.

\section{Acknowledgements}

The authors thank British Columbia (BC) Parks for access to Lac Du Bois Provincial Park. Brandy Ludwig and Amber Greenall assisted with field work and photo analysis. This project was supported by the BC Ministry of Environment, an Industrial NSERC through partnership with the Grasslands Conservation Council of B.C. to C.N.C., and an NSERC DG to L.H.F.

\section{References}

Ammon, E.M., Stacey, P.B., 1997. Avian nest success in relation to past grazing regimes in a montane riparian system. Condor $99,7-13$.

Bias, M.A., Morrison, M.L., 2006. Habitat selection of the salt marsh harvest mouse and sympatric rodent species. J. Wild. Manage. 70, 732-742.

Block, W.M., With, K.A., Morrison, M.L., 1987. On measuring bird habitat: influence of observer variability and sample size. Condor 89, 241-251.

Boyd, C.S., Svejcar, T.J., 2005. A visual obstruction technique for photo monitoring of willow clumps. Range. Ecol. Manage. 58, 434-438.

Brennan, L.A., Kuvlesky Jr., W.P., 2005. North American grassland birds: an unfolding conservation crisis? J. Wild. Manage. 69, 1-13.
Collins, W.B., Becker, E.F., 2001. Estimation of horizontal cover. J. Range Manage. 54 67-70.

Duebbert, H.F., Lokemoen, J.T., 1976. Duck nesting in fields of undisturbed grass-legume cover. J. Wild. Manage. 40, 39-49.

Fondell, T.F., Ball, I.J., 2004. Density and success of bird nests relative to grazing on western Montana grasslands. Biol. Cons 117, 203-213.

Fraser, D.F., Harper, W.L., Cannings, S.G., Cooper, J.M., 1999. Rare Birds of British Columbia. Wildl. Branch and Resour. Inv. Branch, B.C. Minist. Environ. Lands and Parks, Victoria, BC. ps. 244.

Ganguli, A.C., Vermeire, L.T., Mitchell, R.B., Wallace, M.C., 2000. Comparison of four nondestructive techniques for estimating standing crop in shortgrass plains. Agron. J. 92, 1211-1215.

Gotfryd, A., Hansell, R., 1985. The impact of observer bias on multivariate analyses of vegetation structure. Oikos 45, 223-234.

Hernández, F., Henke, S.E., Silvy, N.J., Rollins, D., 2003. The use of prickly pear cactus as nesting cover by Northern Bobwhites. J. Wild. Manage. 67, 417-423.

Hitchcock, C.L., Cronquist, A., 1973. Flora of the Pacific Northwest. University of Washington Press, Seattle, WA.

Kimball, S., Mattis, P., 2006. The Gimp 2.2. Available at: http://www.gimp.org/ (accessed 14.07.09.).

Kirsch, L.M., 1974. Habitat management consideration for prairie-chickens. Wild. Soc. Bull. 2, 124-129.

Limb, R.F., Hickman, K.R., Engle, D.M., Norland, J.E., Fuhlendorf, S.D, 2007. Digital photography: reduced investigator variation in visual obstruction measurements for Southern tallgrass prairie. Range. Ecol. Manage. 60, 548-552.

Luque-laren, J.J., López, P., 2007. Microhabitat use by wild-ranging Cabrera voles Microtus cabrerae as revealed by live trapping. Eur. J. Wild. Res. 53, 221-225.

Martin, T.E., Roper, J.J., 1988. Nest predation and nest-site selection of a western population of the hermit thrush. Condor 90, 51-57.

McGarigal, K., McComb, W.C., 1995. Relationships between landscape structure and breeding birds in the Oregon coast range. Ecol. Mono 65, 235-260.

Moynahan, B.J., Lindberg, M.S., Thomas, J.W., 2006. Factors contributing to process variance in annual survival of female greater sage-grouse in Montana. Ecol. Appl. 16, 1529-1538.

Pitman, J.C., Hagen, C.A., Robel, R.J., Loughin, T.M., Applegate, R.D., 2005. Location and success of Lesser Prairie-chicken nests in relation to vegetation and human disturbance. J. Wild. Manage. 69, 1259-1269.

R Development Core Team, 2006. R 2.4.0 - A Language and Environment.

Reese, P.E., Volensky, J.D., Schacht, W.H., 2001. Cover for wildlife after summer grazing on Sandhills rangeland. J. Range Manage. 54, 126-131.

Renfrew, R.B., Ribic, C.A., Nack, J.L., 2005. Edge avoidance by nesting grassland birds: a futile strategy in a fragmented landscape. Auk 122, 618-636.

Robel, R.J., Briggs, J.N., Dayton, A.D., Hulbert, L.C., 1970. Relationships between visual obstruction measurements and weight of grassland vegetations. J. Range Manage. 23, 295-297.

Sutter, G.C., Brigham, R.M., 1998. Avifaunal and habitat changes resulting from conversion of native prairie to crested wheat grass: patterns at songbird community and species levels. Can. J. Zool. 76, 869-875.

Tisdale, E.W., 1947. The grasslands of the southern interior of British Columbia. Eco 28, 346-382.

Todd, L.D., Poulin, R.G., Wellicome, T.I., Brigham, R.M., 2003. Post-fledging survival of burrowing owls in Saskatchewan. J. Wild. Manage. 67, 512-519.

Warren, K.A., Anderson, J.T., 2005. Grassland songbird nest-site selection and response to mowing in West Virginia. Wild. Soc. Bull. 33, 285-292.

West, B.C., Messmer, T.A., 2006. Effects of livestock grazing on duck nesting habitat in Utah. Range. Ecol. Manage. 59, 208-211.

Winter, M., Johnson, D.H., Shaffer, J.A., 2005. Variability in vegetation effects on density and nesting success of grassland birds. J. Wild. Manage. 69, 185-197. 